Joanna Pacewicz-Biegańska

Uniwersytet Gdański

\title{
Pornografia jako świat wyobrażony kobiecej i męskiej seksualności
}

\author{
Pornografia to w istocie rzeczy tylko \\ paradoksalna granica seksualności. \\ Realistyczne "wyolbrzymienie", \\ maniakalne natręctwo seksualności.
}

J. Baudrillard

Jest wiele publikacji mówiących o zagrożeniach, jakie niesie za sobą pornografia, na przykład książka doktora psychologii Victora Cline'a Skutki pornografii: dowody eksperymentalne i kliniczne czy Szkodliwość pornografii Jerry'ego Kirka. Pozycje te mówią o uzależnieniu od pornografii, o tym, że pobudza ona do dewiacji, agresji, przemocy, że wypacza obraz aktu seksualnego i potrafi niszczyć relacje międzyludzkie. To wszystko prawda, ale dlaczego tak się dzieje? Ten tekst jest refleksją nad zjawiskiem pornografii. Warto podjąć rozważania dotyczące jej istoty. Czy jest jak film fantastyczny, wykreowany po to, aby uwieść widza i wprowadzić go w nierealny, wyobrażony świat? Czy jest to po prostu sztuka pokazująca różnego rodzaju i w różny sposób urozmaicane stosunki seksualne? Warto także przyjrzeć się rodzajom pornografii. Twórcą jednej z bardziej znanych klasyfikacji jest David Alexander Scott. Dzieli on pornografię na:

- pornografię typu "soft-core" (pornografia miękka) - są to materiały przedstawiające heteroseksualne sceny erotyczne bez użycia przemocy, na przykład sceny nagości z ekspresją seksualną, dewiacje o małym stopniu wyrafinowania, seks, na który obie strony wyrażają zgodę (Scott 1995: 13);

- pornografię typu "hard-core” (pornografia twarda) - występują tu zachowania dewiacyjne, przemoc, pedofilia, zoofilia, zboczenia. Są to materiały przedstawiające nietypowe zachowania seksualne, jak na przykład orgie, gwałty, sadomasochizm (Scott 1995: 79).

Artykuł ten dotyczy pornografii ukazującej wyłącznie stosunki heteroseksualne, wpisującej się w kategorię pornografii miękkiej.

Chociaż pornografia jest znana od wieków i dzisiaj każdy wie, czym jest, to bardzo ciężko zbudować jej precyzyjną, naukową definicję. Etymologicznie słowo „pornografia” oznacza "nierządne rysunki” (z greckiego: porne - nierządny, graphos - rysować, rysunek) (Krawulska-Ptaszyńska 2003: 14). 
Współcześnie popularnym rodzajem pornografii są krótkometrażowe filmy zamieszczane na stronach internetowych. Warto jednak pamiętać, że taka forma pornografii jest stosunkowo nowa. Dawniej z oczywistych przyczyn istniały jedynie wspomniane "nierządne rysunki". Naukowcy zainteresowani zjawiskiem pornografii podejmują próby jej zdefiniowania, ale nie udało się ustalić jednej, uniwersalnie obowiązującej definicji tego zjawiska. Anna Krawulska-Ptaszyńska za pornografię uznaje „wszystkie wytwory, które koncentrują się na eksponowaniu aktywności seksualnej i/lub sfery genitalnej, co do których możemy przypuszczać, że zostały wykonane w celu wzbudzenia podniecenia seksualnego u określonego kręgu odbiorców, które podniecenie to rzeczywiście wywołują" (Krawulska-Ptaszyńska 2003: 15). Można tutaj podać w wątpliwość uznanie podniecenia seksualnego jako wyznacznika pornografii, bowiem nie wszystkie wytwory mające wywołać podniecenie seksualne, rzeczywiście je wywołują, a czasem podniecenie może wywołać coś, co absolutnie nie miało tego na celu, na przykład scena z filmu niepornograficznego lub jakieś dzieło sztuki (rzeźba, obraz itp.). Wendy McElroy proponuje bardziej zwięzłą definicję: „Pornografia to artystyczne przedstawienia kobiet i mężczyzn jako istot jednoznacznie seksualnych" (McElroy 1995: 51). Ta definicja również jest dyskusyjna, ponieważ każdy mężczyzna i każda kobieta mogą być w dowolnej chwili postrzegani jako istoty jednoznacznie seksualne. Co więcej, kategoria artyzmu ma charakter bardzo subiektywny - zdaniem jednej osoby takie przedstawianie kobiet i mężczyzn może być artystyczne, a zdaniem drugiej nie. Autorem kolejnej definicji jest Władysław Bernard Skrzydlewski. Twierdzi on, że „pornografia to wszelkie wytwory, które uważa się za powodujące pobudzenie seksualne normalnego człowieka" (Skrzydlewski 2003: 83). Tutaj znowu pojawia się sugestia, że jeżeli podniecenie seksualne występuje, to dane zjawisko jest pornografią, a przecież jest to założenie nieprecyzyjne. Myślę, że tak trudno zdefiniować pornografię, ponieważ wiąże się ona z wrażliwością człowieka. Obsceniczność danego obrazu, filmu, reklamy jest kwestią subiektywną - to, co dla jednych zakrawa o pornografię, dla innych jest naturalne. Słuszne wydaje się stwierdzenie:

Pornografia jest definiowana przede wszystkim przez funkcję, którą rozumiemy jako podniecenie użytkownika, prowadzące do aktywności seksualnej w formie stosunku lub masturbacji. Nie znaczy to, że przedstawienia, które nie są pornografią, nie mogą mieć charakteru erotycznego (być podniecające seksualnie), ani też, że cała pornografia wywołuje podniecenie (McNair 2004: 167).

Jest to w mojej opinii najbardziej trafna próba zdefiniowania tego niejednoznacznego zjawiska.

Współcześnie pornografia jest problemem na ogromną skalę ze względu na powszechność internetu. Jeszcze kilkanaście lat temu niewiele osób miało tak swobodny dostęp do materiałów pornograficznych, a żeby je zdobyć, trzeba było często podjąć pewien wysiłek, nawet przełamać wstyd - wypożyczając kasetę VHS z filmem pornograficznym lub kupując pornograficzną gazetę $\mathrm{w}$ kiosku, nie byliśmy już tak anonimowi jak teraz, gdy siedzimy w zaciszu domowym i przeglądamy szeroki wybór stron pornograficznych (McNair 2004: 168). Według badań Stanisława Kozaka ponad 40 milionów ludzi na świecie regularnie ogląda strony pornograficzne, z czego $20 \%$ mężczyzn i $12 \%$ kobiet robi to w godzinach 
pracy. Badania te dowiodły również, że największą grupą oglądającą pornografię są bardzo młodzi ludzie w przedziale wiekowym od dziesięciu do siedemnastu lat (Kozak 2007: 85). Internet jest na tyle "spornografizowany”, że więcej jest stron internetowych pod hasłem „seks” lub „porno” niż pod hasłem „Bóg” (Pilśniak 2005: 41). Jest to szczególne zagrożenie dla młodych osób, które są ciekawe świata i szybko ekscytują się tym, co "zakazane”. Dzieci to bardzo łatwy cel dla osób, które rozpowszechniają pornografię - pokazują to badania Anny Wrony, mówiące między innymi o tym, że w 2008 roku $80 \%$ dzieci natrafiło w internecie wbrew woli na materiały o charakterze pornograficznym, a połowa nieletnich otrzymała w wiadomościach e-mail linki do stron pornograficznych. Duża część wyżej wymienionych nieletnich zgłasza, że nie są to jednorazowe incydenty (kilka razy $36 \%$, wiele razy - 29\%). Blisko połowa badanych (49\%), którzy jednorazowo lub wielokrotnie otrzymali link do strony pornograficznej w wiadomościach e-mail, skorzystało z niego (29\% - wielokrotnie) (Wrona 2009: 315). Młodzi ludzie, dopiero kształtujący i poznający swoją seksualność, nie powinni oglądać scen, w których seks i ludzka seksualność są wypaczone i zniekształcone do granic możliwości. W dzisiejszych czasach jednak niemożliwe jest, aby młody człowiek nigdy nie zetknął się z pornografią, ponieważ istnieje ona w mass mediach - wiele reklam, teledysków czy seriali oscyluje na pograniczu pornografii, a granica ta ciągle jest przesuwana coraz dalej. W związku z tym warto rozmawiać na ten temat z młodzieżą. Taka rozmowa jednak nie powinna polegać na zakazywaniu lecz na dystansowaniu nieletniego do tego, co oferuje kultura popularna.

Warto bliżej przyjrzeć się wizerunkowi kobiety w materiałach pornograficznych. Po pierwsze trzeba zauważyć, że w heteroseksualnej, miękkiej pornografii najczęściej to kobieta prowokuje aktywność seksualną. To ona pręży się i wije przed mężczyzną, prosząc go i zachęcając do stosunku. Jednocześnie pokazuje, że jest zdolna do poddania się wszelkim praktykom i pomysłom, jakie przyjdą do głowy mężczyźnie. Pornografia

jest to z reguły przedstawiona w ściśle określony sposób rozkosz seksualna, ale nie mężczyzny, tylko kobiety. To opowieść o kobietach w ekstazie seksualnej, ale zawsze pod władaniem fallusa. Kobieta jęczy, dyszy i drży, ale to milczący mężczyzna aranżuje i kontroluje przebieg zdarzeń (Giddens 2006: 156).

Kobieca seksualność jest zatem totalnie uprzedmiotowiona i podległa mężczyźnie. Kobieta w heteroseksualnej, miękkiej pornografii odgrywa rolę zabawki w męskich rękach. Anna Krawulska-Ptaszyńska pisze, że w pornografii postać kobiety pozbawia się człowieczeństwa i przedstawia jako gorszą od mężczyzny (Krawulska-Ptaszyńska 2003: 24). W tego typu materiałach pornograficznych bez trudu można zauważyć bierność kobiety. Działanie jest domeną mężczyzny, kobieta zaś to jedynie obiekt, na którym skupia się owo działanie, któremu jest ona całkowicie podporządkowana. „Pornograficzna inscenizacja jest jednak napiętnowana mężczyzną, a kobiecie i jej roli - pozostawia jedynie wąski margines" (Hajkowski 2012: 3). Dzieje się tak, ponieważ pornografia z założenia jest skierowana do mężczyzn i to jeden $z$ nich dominuje podczas intensywnego seksu, pozbawionego jakichkolwiek uczuć i emocji, a kobieta jest ukazywana skrajnie stereotypowo - czyli jako osoba służąca do zaspokojenia męskiego pożądania i jego wszelkich wyuzdanych zachcianek (Giddens 2006: 154). 
Wizerunek mężczyzny $\mathrm{w}$ omawianej kategorii pornografii jest kreowany w sposób przeciwny. Jest on głównym bohaterem, panem sytuacji, który decyduje o tym, jak będzie wyglądał akt seksualny. To postać niezwykle silna, władcza, dobrze zbudowana i sprawna seksualnie, a także wyzuta z emocji i jakichkolwiek skrupułów. Kobieta jest dla niego atrakcją, czymś, co można bez problemu i konsekwencji wykorzystać i zostawić. Ponadto przedstawienie jego cielesności również jest charakterystyczne. Klasyczny męski bohater filmów pornograficznych ma niezwykle rozbudowaną i umięśnioną klatkę piersiową, nogi i ręce. Jest uosobieniem siły i władzy. Jego nienaturalnych rozmiarów przyrodzenie odgrywa bardzo ważną rolę, ponieważ jest głównym atutem mężczyzny. Jest dumą dla właściciela i obiektem pożądania kobiet. Rozmiar narządów płciowych decyduje o męskości i wartości mężczyzny oraz kobiecym podziwie i fascynacji. Tak przedstawiony męski wizerunek może negatywnie wpływać na myślenie o własnej cielesności wśród młodych chłopców. Przejawia się to zazwyczaj w nagminnym dbaniu o wygląd zewnętrzny - obsesja na punkcie muskulatury (bigoreksja), uzależnienie od sterydów lub innych substancji chemicznych powodujących przyrost tkanki mięśniowej oraz kompleks "małego członka” to tylko niektóre z problemów współczesnych nastolatków. Skąd bierze się tak silne dążenie do perfekcyjnego ciała?

Młodzi ludzie, patrząc na takie nienaturalne oblicze kobiet i mężczyzn, mają zaburzony wizerunek kobiecości i męskości. Chłopcy mogą interpretować sceny pornograficzne $\mathrm{w}$ taki sposób, że wszystkie kobiety i dziewczyny nieustannie mają ochotę na seks i można z nimi robić wszystko, cokolwiek wyobraźnia podpowie. Zanika tutaj szacunek do partnerki i do jej potrzeb oraz preferencji. Dziewczęta zaś mogą pomyśleć, że w sytuacji intymnej trzeba zgadzać się na wszystko, czego zażyczy sobie partner, oraz że zawsze należy być gotową i chętną do współżycia seksualnego. Ponadto może wytworzyć się w nich przekonanie, że mężczyzna podczas aktu seksualnego ma prawo z kobietą zrobić wszystko, nawet ją poniżać i gwałcić, bowiem wizerunek mężczyzny w pornografii promuje zapewnianie sobie przyjemności bez poszanowania uczuć drugiej osoby, przy pomocy siły i agresji. Pokazuje mężczyznę jako tyrana i człowieka, który jest niezwykle bezwzględny w momencie podniecenia seksualnego.

Sam akt seksualny jest przedstawiany w sposób bardzo nienaturalny, wyreżyserowany i nierzadko wręcz wulgarny. Podczas stosunku nie ma mowy o żadnych uczuciach czy trosce o partnera. Ważne jest tylko zaspokojenie pożądania. Skrzydlewski pisał, że:

[...] zachowanie seksualne człowieka z natury intymne, pornografia odziera $\mathrm{z}$ tej intymności i na dodatek robi to często w sposób brutalny. Miłość w pornografii właściwie nie istnieje, a przynajmniej nie ma znaczenia. Każdy człowiek, który jest jednocześnie partnerem, jest traktowany przedmiotowo - nie jako obdarzona godnością osoba, ale jako przedmiot zaspokajania pożądań seksualnych. Przy czym bardzo często połączone jest to $\mathrm{z}$ zachowaniem seksualnym agresywnym, brutalnym i wulgarnym. Pornografia pokazuje też zmiany partnerów seksualnych jako coś normalnego, nie pokazuje natomiast częstych i tragicznych w rzeczywistości skutków przedstawianych zachowań seksualnych (Skrzydlewski 2003: 85). 
Ten brak konsekwencji, o którym wspomina Skrzydlewski, jest dla pornografii charakterystyczny. Pornografia jest jednowymiarowa, jednowątkowa - pokazuje tylko sam akt seksualny, zaś jego konsekwencje w dalszym życiu pomija milczeniem. Młodzi ludzie często nie są świadomi, że takie postępowanie grozi utratą wartości, godności oraz szacunku do samego siebie, różnego rodzaju chorobami przenoszonymi drogą płciową i w końcu niechcianą ciążą. O tym w pornografii absolutnie nie ma mowy.

Brian McNair, autor książki Seks, demokratyzacja pożądania i media, czyli kultura obnażania, zauważa, że w materiałach pornograficznych

zawsze obecne jest pożądanie, a "nie” znaczy zwykle „tak”. W pornografii ograniczenia, obowiązki i odpowiedzialność, które określają i strukturują stosunki seksualne w realnym życiu - jak na przykład małżeństwo i wychowanie dzieci - niemal zawsze są nieobecne. Świat pornografii to świat idealny, w którym przynajmniej wówczas, gdy konsument jest w nim zanurzony - życie ogranicza się do mechanizmów związanych z aktem płciowym (McNair 2004: 123).

Tak jak twierdzi McNair, pornografia jest „oderwana” od rzeczywistości, ponieważ przedstawia tylko seks i niewiele jest w niej wątków poza aktem seksualnym. Prawdopodobnie właśnie to najbardziej pociąga i interesuje odbiorców tego typu materiałów. Ale jest to również zagrożenie, bowiem ten "świat idealny”, o którym pisze McNair w powyższym cytacie, bardzo często uzależnia i przesłania obraz świata realnego. Młode osoby powinny wiedzieć o tym, że seks w pornografii nie jest realny - że jest to jedynie wizja reżysera bądź producenta i że w rzeczywistości może on wyglądać zupełnie inaczej. Chodzi tu o zbudowanie dystansu do pornograficznych scen, tak aby nie rzutowały one na prawdziwe życie nastolatków.

Niezwykle ciekawą i wpisującą się w temat niniejszego artykułu jest publikacja Lecha Nijakowskiego Ciało w zwierciadle pornografii. Autor opisuje w niej sposób ukazywania ludzkiego ciała w zależności od rodzaju pornografii i wskazuje na konsekwencje tego zjawiska. „Pornografia wpływa na odbiorców na głębszym poziomie. Prezentując ciała z pozoru zdrowe i zadbane, wpisuje się w dyskurs biowładzy, nakazując nieustanną troskę o siebie" (Nijakowski 2015: 31). Ponadto Nijakowski obala mity związane z zagadnieniem pornografii. Jednym z takowych mitów jest bagatelizowanie pornografii jako materiału badawczego dla świata nauki i uznanie jej za mało poważny i mało wartościowy temat dla badaczy życia społecznego.

Tymczasem pornografia jest zjawiskiem totalnym - odsyła do wielu sfer życia, reprezentuje uświadamiane i nieuświadamiane trendy społeczne. Reaguje niezwykle szybko na zmiany stylów życia, przemiany w sferze norm i wartości oraz postaw wobec społecznych tabu lub na pojawianie się nowych form gospodarowania. Nie stanowi idealnego zwierciadła - wiele zjawisk wykrzywia i wyolbrzymia - ale przyglądając się jej okiem uzbrojonym w naukowe szkło powiększające, można dostrzec wiele prawd o społeczeństwach daną pornografię produkujących i ją konsumujących (Nijakowski 2015: 32). 
Warto zatem przyglądać się zmianom i zjawiskom, które zachodzą na tym polu, a także badać opinie społeczne dotyczące tego, w jaki sposób pornografia jest postrzegana, jakie są jej konsekwencje i przejawy we współczesnym świecie.

Próbę takowych badań podjęłam w kwietniu 2015 roku. Przeprowadziłam je wśród studentów i studentek studiów magisterskich $\mathrm{z}$ kierunku pedagogika na Uniwersytecie Gdańskim. Były to badania jakościowe, bowiem badani przeze mnie studenci mieli za zadanie odpowiedzieć na jedno pytanie otwarte, które dawało pole do refleksji i możliwość bardzo rozbudowanej wypowiedzi. Pytanie zadane studentom brzmiało: „Jaki jest Twoim zdaniem wizerunek kobiety i mężczyzny w materiałach/filmach pornograficznych?" Respondenci pisali odpowiedzi na wcześniej przygotowanych kartkach. Badanie to miało na celu poznanie opinii studentów na temat tego, w jaki sposób postrzegają oni kobiety i mężczyzn występujących w pornografii.

W badaniu wzięło udział 111 osób z czego dziewięć nie wypowiedziało się na ten temat, usprawiedliwiając się tym, że nigdy nie miało do czynienia z pornografią. Zastanawiające, czy we współczesnym świecie możliwe jest, aby osoba mająca ponad dwadzieścia lat nigdy choć na chwilę lub przypadkowo nie spotkała się z pornografią. Być może jest to tylko usprawiedliwienie niechęci wypowiedzenia się na ten temat. Pozostali respondenci zgodnie twierdzili, że wizerunek zarówno kobiety, jak i mężczyzny jest sztuczny i mija się z prawdą. Wiele odpowiedzi opisywało wygląd zewnętrzny bohaterów pornografii:

W filmach pornograficznych zauważam bardzo dużą sztuczność i nieprawdziwość. Wielkie rozmiary penisów, sztuczne udawanie orgazmu kobiety. W wizerunku zarówno kobiety, jak i mężczyzny można doszukiwać się czegoś w rodzaju „animalności" rozumianej jako zwierzęcego kopulowania, czasem brutalnego, ponieważ kobieta jest najczęściej sponiewierana i traktowana przedmiotowo, tylko jako przedmiot do wykorzystania. Uważam, że ciało obojga jest bardzo sztuczne i nieprawdziwe, na potrzeby filmu. Tak jak wcześniej wspomniałem, przypomina to raczej orygialny obrzęd, czego finałem zawsze jest wytrysk mężczyzny.

Powstaje nowy typ ideału kobiecego. Kobiety powinny być szczupłe, z dużym (sztucznym), niemożliwie jędrnym biustem oraz pośladkami. Jak wiemy, takiego ciała nie da się uzyskać poprzez geny i ćwiczenia fizyczne - skutkuje to coraz częstszymi wizytami kobiet u chirurgów plastycznych, ponieważ „normalne” kobiety popadają w kompleksy, a czasem nawet w depresję.

Kobieta jest ukazywana jako zniewolona wobec mężczyzny (zazwyczaj). Podporządkowuje wszystkie czynności wobec mężczyzny. Jest to kobieta najczęściej po operacji plastycznej powiększenia piersi, wydepilowana, wyzwolona, zdolna do wszelkich "zabaw" seksualnych i gotowa do poniżania. Mężczyzna jest pokazany jako władczy, mający kontrolę nad kobietą. Jego ciało jest umięśnione, przyrodzenie jest pokaźne i kondycja godna podziwu.

Respondenci zwrócili uwagę na widoczną od pierwszej chwili iluzoryczność wyglądu zewnętrznego bohaterów. Co więcej, druga wypowiedź akcentuje problem kultu pięknego, młodego ciała. Zjawisko to jest obecne nie tylko w pornografii, ale również $\mathrm{w}$ szeroko pojętych mediach, które propagują dążenie do bardzo szczupłej sylwetki, idealnych kształtów i ciała bez jakiejkolwiek skazy. 
Mamy tu do czynienia z problemem zauważonym także przez wcześniej wspomnianego socjologa Lecha Nijakowskiego, który mówi o "dyskursie biowładzy” w pornografii. Respondent lub respondentka zauważa, że prowadzi to do często niebezpiecznych i ryzykownych zabiegów chirurgicznych oraz do depresji spowodowanej ciągłym dążeniem do niemożliwego do osiągnięcia ideału.

Kolejną istotną rzeczą zauważoną przez badanych jest odmienne traktowanie aktorów i aktorek biorących udział w filmach pornograficznych:

Części intymne kobiety pokazywane częściej i w całości, natomiast mężczyzny są ukryte, niewidoczne. Jest większe przyzwolenie na pokazywanie nagiej kobiety niż mężczyzny.

Mężczyzna w pornografii nie musi być przystojny, może być gruby, brzydki, a i tak każdą kobietę bierze jak przedmiot.

Być może dzieje się tak, ponieważ większość materiałów pornograficznych kierowana jest do mężczyzn - dlatego występuje w nich głównie skupienie uwagi na cielesności kobiety (która musi być atrakcyjna i zachęcająca), aniżeli na ciele mężczyzny.

Widać, że respondenci - podobnie jak Lech Nijakowski - zauważają tendencje do ukazywania ludzkiej fizyczności jako „ciało cukierkowe”, które tworzy „bajkową reprezentację":

Mężczyzna jako dominator, umięśniony, z ogromnym przyrodzeniem. Kobieta jest poniżana, traktowana jak przedmiot, wygląda bardzo sztucznie - sztuczna opalenizna, biust, paznokcie, włosy, mocny makijaż, w niczym nie przypomina ludzi, których normalnie spotykamy na ulicach, mają idealne ciała, bez grama tłuszczu, cellulitu, bez rozstępów, jędrne ciała...

Uważam, że mężczyzna w materiałach pornograficznych kreowany jest jako dominator, kobieta natomiast jest ukazana jako uległa, która ma za zadanie spełniać zachcianki mężczyzny. Przeważnie kobieta jest po wielu operacjach plastycznych. Widać, że udaje orgazm, nawet gdy czynności wykonywane nie sprawiają jej faktycznej przyjemności.

Moim zdaniem wizerunek kobiet i mężczyzn w filmach pornograficznych jest sztuczny. Mężczyźni są zawsze umięśnionymi macho, kobiety z kolei nieporadnymi, biuściastymi, gotowymi na wszystko kociakami. Są poniżane.

Badani bardzo wyraźnie określali (choć nie było o to prośby w pytaniu), do czego może prowadzić częste korzystanie z pornografii:

Mężczyźni, oglądając takie filmy, mają niewiadomo jakie wyobrażenie o kobiecie w sypialni. Oczekują od kobiet zbyt wiele, nie dając czasem nic w zamian.

Młodzi ludzie, oglądając takie rzeczy, kreują i postrzegają rzeczywistość, której nie ma. I są tym wszystkim później rozczarowani. Dochodzi do rozpadów w związkach i ponieważ ludzie mają zbyt wygórowane oczekiwania wobec partnera.

Młodzież oglądająca filmy pornograficzne sądzi, że tak właśnie wygląda stosunek w życiu, że seks zawsze kończy się orgazmem, a partner zawsze jest gotowy; że 
mężczyzna czy kobieta zawsze mają modelowe ciała. Jest to wizerunek zupełnie nieprawdziwy, wprowadzający w błąd młodego człowieka.

Na koniec przytoczę jeszcze cztery cytaty, które mówią o tym, do czego (najczęściej) jest sprowadzana rola kobiety w pornografii:

Moim zdaniem wizerunek kobiety w materiałach/filmach pornograficznych kreowany jest na służącą lub niewolnicę seksualną. Kobieta służy zaspokojeniu fantazji i potrzeb „Pana i Władcy”, w tym wypadku mężczyzny/mężczyzn w filmach pornograficznych. Mężczyzna pełni w nich rolę władcy, który może zrobić, co mu się tylko podoba ze swoją niewolnicą, a ona ma za zadanie się jemu poddać. Mężczyzna emanuje swoją siłą i męskością, a kobieta ukazywana jest jako uległa lub też nie mogąca podejmować decyzji, a zarazem wyuzdana postać.

Kobieta jest traktowana jako przedmiot, z którym można zrobić wszystko, łącznie z poniżaniem i przemocą, a ona jeszcze za to podziękuje.

Mężczyzna jest beneficjentem usług, które kobieta musi mu dostarczyć.

Kobieta ukazana jest jako zabawka służąca mężczyźnie. Nawet jeśli zdarza się, że odgrywa rolę dominującą, to wynika to z konwencji mężczyzny. Jest zabawką, która posłusznie spełnia wszystkie zachcianki mężczyzny bez możliwości sprzeciwienia się („Ciągnie mnie za włosy? E tam, chwilę wytrzymam”).

Studenci pedagogiki widzą zagrożenia, jakie niesie pornografia, i dostrzegają możliwe, niebezpieczne konsekwencje, na przykład: zbyt duże wymagania seksualne wobec partnera/partnerki, rozpady związków, brak szacunku do kobiet/ mężczyzn.

Badane osoby wyraźnie mówią, że wygląd zewnętrzny bohaterów pornografii jest sztuczny i nieprawdziwy, zdają sobie sprawę, że aktorki porno często poddają się operacjom plastycznym. Co więcej, wiedzą, że akt seksualny przedstawiany w filmach pornograficznych niekoniecznie wygląda tak, jak w realnym życiu - „seks jest wyreżyserowany, przez co staje się bardzo sztuczny”. Często w wypowiedziach powtarzały się wątki mówiące o poniżaniu kobiet i o traktowaniu ich przedmiotowo, jak zabawki, jak własność mężczyzny. Wszystkie te uwagi świadczą o dojrzałości respondentów.

Jest to pozytywny wniosek, tym bardziej że badani to osoby, które w przyszłości prawdopodobnie będą pracować z młodzieżą, i ich obowiązkiem będzie takie ukierunkowanie młodych ludzi, aby byli zdystansowani do świata prezentowanego przez pornografię. Problem pornografii bowiem nie zniknie, a raczej będzie rosnąć w siłę, ponieważ to zjawisko „ukazuje tajemnice prywatnej sfery cielesnego pożądania w całej ich transgresyjnej, łamiącej tabu egzotyczności. Z założenia jest ona pogwałceniem publicznej moralności i smaku, afrontem wobec norm - jakiekolwiek by one były - przyjętych przez społeczność w sferze przedstawień o treściach seksualnych" (McNair 2004: 125). Atrakcyjność pornografii polega na łamaniu tabu i dopóki będzie ono łamane, dopóty będzie ona istnieć. Przeprowadzone badania wyraźnie pokazują, że respondenci patrzą z dystansem na materiały pornograficzne, ale jest to akurat grupa osób studiujących, o wysokiej świadomości i wiedzy ogólnej. Jest jednak wysoce prawdopodobne, że 
przeprowadzenie takich badań wśród innych grup społecznych wykazałby niższy poziom świadomości, a wyniki byłyby niezadowalające.

Powyższy artykuł podsumować można myślą Gail Dines, autorki książki Pornoland. Jak skradziono nasza seksualność. Powiedziała ona, że „Pornografia jest tak głęboko zakorzeniona w naszej kulturze, iż stała się synonimem seksu. Prowadzi do tego, że każdy, kto ją krytykuje, natychmiast zostaje obwołany wrogiem seksu" (Dines 2012: 36). Trudno się z tym nie zgodzić; przerażająca jest myśl, że obrazy i sceny, które widzimy w pornografii, mogą być dla kogoś odpowiednikiem lub uosobieniem prawdziwego życia seksualnego. Należy jak najwięcej rozmawiać o tym, że pornografia to nie synonim seksu, a jego przedstawienie w innym świetle, że jest to akt seksualny pokazany w sposób sztuczny - bez jakichkolwiek emocji, uczuć i piękna, które normalnie powinny być obecne podczas współżycia seksualnego. Warto podejmować te tematy z młodzieżą, bo to oni są grupą najbardziej wrażliwą i przez to najbardziej narażoną na "pornograficzny fałsz" przedstawionej tam ludzkiej seksualności.

\section{Literatura:}

Dines G, 2012, Pornoland. Jak skradziono naszq seksualność, tłum. K. Dajksler, Poznań: Wydawnictwo Polskiej Prowincji Dominikanów „W drodze".

Giddens A., 2006, Przemiany intymności. Seksualność, miłość i erotyzm we wspótczesnych społeczeństwach, tłum. A. Szulżycka, Warszawa: PWN.

Hajkowski M., 2012, Pornografia i męska dominacja - sposoby obrazowania kobiecych i męskich przyjemności w filmach pornograficznych, „Palimpsest” nr 2.

Kozak S., 2007, Patologie wśród dzieci i młodzieży. Leczenie i profilaktyka, Warszawa: Centrum Doradztwa i Informacji Difin.

Krawulska-Ptaszyńska A., 2003, Psychospołeczne uwarunkowania korzystania z pornografii przez mężczyzn, Poznań: Wydawnictwo Naukowe Bogucki.

McElroy W., 1995, XXX: A Women's Rights to Pornography, New York: St. Martin's Press.

McNair B., 2004, Seks, demokratyzacja pożądania i media, czyli kultura obnażania, tłum. E. Klekot, Warszawa: Wydawnictwo Muza.

Nijakowski L., 2015, Ciało w zwierciadle pornografii, "Znak" nr 717.

Pilśniak M., 2005, Seks, wiara i internet, „List” nr 2.

Scott D.A., 1995, Pornografia: jej wpływ na rodzinę społeczeństwo, kulturę, tłum. K. Ostrowska, Gdańsk: Human International Life.

Skrzydlewski W.B., 2003, Palące problemy seksualności, Kraków: Wydawnictwo M.

Wrona A., 2009, Cyberpornografia i cyberseks [w:] Cyberświat - możliwości i zagrożenia, red. J. Bednarek, A. Andrzejewska Warszawa: Wydawnictwo Żak.

\section{Abstrakt}

Artykuł porusza problem pornografii jako zjawiska, które wypacza myślenie o ludzkich związkach i seksualności. W tekście podjęto próbę pokazania nienaturalności wizerunku kobiety i mężczyzny w materiałach pornograficznych. Ponadto przedstawiono w nim badania własne mówiące o tym, jak studenci pedagogiki postrzegają sposób pokazywania kobiety i mężczyzny w pornografii. Celem artykułu jest udowodnienie, że materiały pornograficzne propagują nierzeczywisty obraz zarówno męskiej, jak i kobiecej seksualności, co jest dużym problemem społecznym oraz pedagogicznym, zniekształcającym myślenie młodego człowieka o tak ważnych sferach jak seksualność i tworzenie relacji partnerskich z drugą osobą. 


\section{Słowa kluczowe}

akt seksualny, kobieta, mężczyzna, pornografia, seksualność

\section{Summary}

Pornography as Imaginary World of Female and Male Sexuality

The article raises the problem of pornography as a phenomenon which distorts thinking about human relationships and sexuality. The text is an attempt to show how unnatural is the image of a woman and a man in pornographic images. In addition, it presents its own research concerning how pedagogy students perceive a way that shows the woman and man in pornography. This article aims to prove that the pornographic material promote an unreal image of both male and female sexuality, which is a big social and pedagogical problem, deforming young man thinking about such an important sphere of what is sexuality and the creation of partnerships with the other person.

\section{Keywords}

the sexual act, women, man, pornography, sexuality 